\title{
Profitabilitas Sebagai Pemoderasi Pengaruh Pengungkapan Sustainability Reporting Pada Nilai Perusahaan Pemenang Indonesian Sustainability Reporting Awards
}

\author{
Quita Amelia Budiana ${ }^{1}$ \\ Fakultas Ekonomi dan Bisnis \\ Universitas Udayana, Indonesia \\ Email: quitamelia@gmail.com
}

\author{
I Gusti Ayu Nyoman Budiasih² \\ Fakultas Ekonomi dan Bisnis \\ Universitas Udayana, Indonesia
}

\begin{abstract}
ABSTRAK
Penelitian ini bertujuan untuk mengetahui pengaruh Sustainability Reporting pada nilai perusahaan dan mengetahui kemampuan profitabilitas dalam memoderasi pengaruh Sustainability Reporting pada nilai perusahaan. Penelitian ini dilakukan pada pemenang Indonesian Sustainability Reporting Awards (ISRA) pada tahun 2015-2018. Jumlah sampel yang diambil sebanyak 13 perusahaan dengan menggunakan teknik purposive sampling. Teknik analisis data yang digunakan adalah Moderated Regression Analysis (MRA). Berdasarkan hasil analisis ditemukan bahwa Sustainability Reporting berpengaruh positif pada nilai perusahaan dan profitabilitas memperkuat pengaruh Sustainability Reporting pada nilai perusahaan.
\end{abstract}

Kata Kunci: Sustainability Reporting; Nilai Perusahaan; Profitabilitas.

Profitability As A Moderating Effect Of Sustainability Reporting Disclosures On Company Values Of Indonesian Sustainability Reporting Awards Winners

\section{ABSTRACT}

This study aims to determine the effect of Sustainability Reporting on firm value and determine the ability of profitability in moderating the effect of Sustainability Reporting on firm value. This research was conducted on the winners of the Indonesian Sustainability Reporting Awards (ISRA) in 2015-2018. The number of samples taken as many as 13 companies using purposive sampling techniques. The data analysis technique used is Moderated Regression Analysis (MRA). Based on the results of the analysis found that Sustainability Reporting has a positive effect on firm value and profitability strengthens the effect of Sustainability Reporting on firm value.

Keywords: $\quad$ Sustainability Reporting; Firm Value; Profitability.

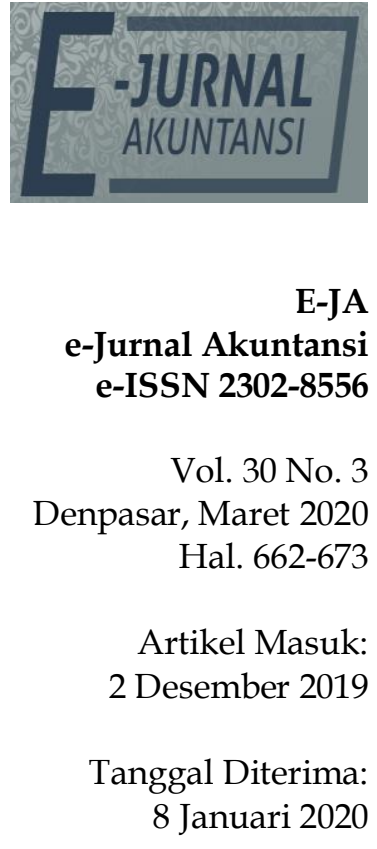




\section{PENDAHULUAN}

Akhir-akhir ini kerusakan lingkungan adalah permasalahan yang serius. Hal tersebut terjadi karena kegiatan ekonomi yang dilakukan diberbagai belahan dunia. Salah satu pelaku yang menyebabkan permasalahan lingkungan adalah perusahaan. Banyak perusahaan yang merusak lingkungan demi untuk meningkatkan keuntungan sendiri. Seiring adanya tuntutan dari masyarakat terhadap perilaku yang dilakukan oleh perusahaan untuk memberikan pertanggungjawaban sosial, maka perusahaan mengembangkan konsep 3P yang diperkenalkan oleh Elkington (1998) yaitu People, Planet, and Profit sering disebut dengan Triple Bottom Line (TBL). Pengungkapan kinerja organisasi dalam sustainability reporting berfokus pada TBL. Robins (2006) menyatakan bahwa konsep TBL berguna untuk mendorong perusahaan agar lebih memperhatikan dampak dari kegiatan bisnis perusahaan, bukan hanya kinerja keuangan saja. Pengungkapan TBL dalam sustainability reporting dapat meningkatkan transparansi mengenai dampak kegiatan ekonomi, sosial, dan lingkungan dari kegiatan perusahaan sehingga perusahaan dapat mengetahui besarnya risiko yang akan dihadapi dan perusahaan dapat menilai peluang dari adanya TBL. GRI-G3 Guidelines (2011) dan Luke \& Adaramola (2013)mengungkapkan bahwa pengungkapan TBL dapat meningkatkan transparansi mengenai dampak kegiatan ekonomi, sosial, dan lingkungan perusahaan yang kemudian akan menjadi pertimbangan dalam keputusan investasi oleh para stakeholders.

Menurut Eva \& Dewi (2015) intensitas pengungkapan sustainability reporting dapat memberikan sinyal baik (good news) atau malah sebaliknya dapat memberikan sinyal buruk (bad news) kepada para pengguna informasi keuangan perusahaan tersebut. Berdasarkan teori sinyal, suatu pengumuman yang mempunyai kandungan informasi akan membuat pasar bereaksi (Zenovia \& Anca, 2009). Reaksi pasar dalam intensitas pengungkapan sustainabilitas dipengaruhi oleh perspektif stakeholders (Aktas et al., 2013). Reaksi tersebut muncul karena perusahaan yang mengungkapkan sustainability reporting meningkatkan kepercayaan stakeholders, reaksi ini dapat dilihat dari kinerja keuangan perusahaan.

Reddy \& Gordon (2010) menujukkan bahwa sustainability reporting berpengaruh signifikan dalam menjelaskan peningkatan profitabilitas perusahaan di Australia. Intensitas pengungkapan ekonomi sangat penting dalam menilai pertumbuhan perusahaan sehingga stakeholders internal dan eksternal akan tertarik (Okoye et al., 2013). Hafni (2018) menunjukkan bahwa terdapat pengaruh positif pengungkapan sustainability reporting terhadap nilai perusahaan pada sector pertambangan yang terdaftar di BEI tahun 2011-2015.

Sedangkan hasil penelitian yang berbeda dari Lesmana \& Tarigan (2014) menunjukkan bahwa intensitas pengungkapan ekonomi dan lingkungan berpengaruh negative pada Return on Asset (ROA). Hal tersebut dikarenakan adanya pengeluaran untuk sustainability activities sebagai biaya tambahan, sehingga menurunkan profit yang seharusnya didapat.

Selain itu penelitian dari Priyadi, (2017) menunjukkan bahwa pengungkapan sustainability reporting tidak berpengaruh terhadap nilai perusahaan baik pada indeks LQ45 maupun indeks JII. Hal tersebut dikarenakan pengungkapan sustainability reporting di Indonesia masih bersifat sukarela 
(valuntary) sehingga perusahaan hanya berfokus pada pelaporan keuangan tahunan saja. Dan itu mengakibatkan banyak perusahaan yang tidak konsisten dalam melaporkan sustainability report disetiap tahunnya.

Inkonsistensi temuan dalam penelitian-penelitian tersebut dapat menjadi alasan untuk dilakukannya penelitian apakah intensitas pengungkapan dalam sustainability reporting berpengaruh pada nilai perusahaan. Semakin banyak perusahaan yang mempublikasikan sustainability reporting membuat adanya gagasan dari IAI dan National Center for Sustainability Reporting (NSCR) mengadakan event penghargaan bernama Indonesian Sustainability Reporting Awards (ISRA) (NCSR,2014).

Pada tahun 2005 Indonesia Sutainability Reporting Awards (ISRA) untuk pertama kalinya diadakan. ISRA adalah suatu ajang penghargaan kepada perusahaan atas transparansi dan akuntabilitas yang diterbitkan pada laporan keberlanjutan (NCSR,2015). Menurut Eva \& Dewi (2015) ajang penghargaan ISRA menciptakan pemenang yang dapat menghasilkan sustainability report yang lebih baik daripada perusahaan yang lain. Apabila perusahaan memiliki penghargaan sustainability report, hal tersebut dapat meningkatkan kualitas perusahaan dalam menyusun laporan keuangan dengan memperhatikan aspek ekonomi, sosial, dan lingkungan sehingga dapat menarik perhatian investor untuk menanam sahamnya di perusahaan yang memenangkannya. Tujuan diadakannya ISRA adalah sebagai bentuk apresiasi pada perusahaan di Indonesia yang telah mempublikasikan laporan keberlanjutan (sustainability reporting), baik yang diinformasikan secara terpisah ataupun menjadi satu dalam laporan tahunan (annual report).

Sebagian perusahan mulai memberi perhatian pada pengungkapan tanggungjawab sosial dan sustainabilitas perusahaan (ncsr-id.org). Dibandingkan tahun sebelumnya, pada tahun 2015 peserta penghargaan ISRA menunjukkan peningkatan positif yaitu sebanyak 37 perusahaan. Ini artinya bahwa sustainability reporting di Indonesia mengalami peningkatan yang baik. Data dari Global Reporting Intiatives (GRI) pada bulan Februari 2016 terdapat 85 perusahaan yang telah mempublikasikan laporannya. Sedangkan pada tahun 2015 sebanyak 63 perusahaan yang mempublikasikan laporannya (sra.ncsrid.org). Hal tersebut terjadi karena banyak perusahaan yang hanya berfokus pada perlaporan keuangannya saja tanpa memperhatikan aspek lainnya sehingga menjadikan perusahaan terancam.

Profitabilitas dipilih sebagai variabel pemoderasi karena variabel ini diduga berpengaruh secara moderating (memperkuat atau memperlemah) hubungan antara sustainability reporting dan nilai perusahaan. Dalam pengambilan keputusan, investor akan lebih tertarik pada perusahaan yang memiliki profitabilitas yang tinggi dan melakukan pengungkapan lingkungan dengan baik. Dan pada akhirnya diharapkan untuk dapat meningkatkan nilai perusahaan (Octavia, 2012). Profitabilitas merupakan kemampuan perusahaan dalam mengelola sumber daya perusahaan untuk menghasilkan keuntungan bagi investor. Profitabilitas berperan penting karena dianggap sebagai indikator dalam mengukur kinerja keuangan suatu perusahaan sehingga dapat dijadikan acuan untuk menilai perusahaan. Teori sinyal menekankan bahwa perusahaan dapat meningkatkan nilai perusahaan dengan memberikan sinyal kepada 
investor melalui pelaporan informasi terkait kinerja perusahaan, sehingga dapat memberikan gambaran akan prospek usaha di masa yang akan datang (Ningrum et al., 2018). Handoko (2010)menyatakan bahwa semakin besar profitabilitas suatu perusahaan, maka semakin baik pula posisi perusahaan tersebut dalam penggunaan aset. Menurut Kusuma secara teoritis, semakin tinggi tingkat profitabilitas perusahaan maka semakin tinggi pula hubungan pengungkapan sosial dengan nilai perusahaan.

Teori stakeholder menyatakan bahwa perusahaan bukan entitas yang beroperasi untuk kepentingan sendiri namun memberikan dampak positif bagi stakeholder-nya. Maka dari itu keberadaan suatu perusahaan sangat dipengaruhi oleh dukungan yang diberikan oleh stakeholder kepada perusahaan tersebut.Upaya untuk memberikan kontribusi positif kepada stakeholder dengan meminimalisir dampak negatif yang timbul dari segala kebijakan dan operasional perusahaan merupakan tanggungjawab perusahaan. Tanggungjawab sosial perusahaan seharusnya dapat melampaui tindakan untuk memaksimalkan laba untuk kepentingan pemegang saham (stakeholder), namun kesejahteraan ditimbulkan perusahaan sebenarnya tidak terbatas pada kepentingan pemegang saham, tetapi untuk kepentingan stakeholder, yaitu semua pihak yang memiliki hubungan dengan perusahaan. Pemegang saham yang memiliki hak terhadap tindakan-tindakan yang dilakukan oleh manajemen perusahaan, stakeholder juga memiliki hak terhadap perusahaan.

Hasil penelitian yang dilakukan oleh Sejati (2015), Kusuma (2018), Kurniawan et al., (2018)menunjukkan bahwa Sustainability Reporting berpengaruh positif pada nilai perusahaan. Perusahaan, investor, masyarakat dan para pemangku kepentingan akan menilai kinerja perusahaan melalui Sustainability Reporting. Nilai suatu perusahaan dikatakan baik apabila perusahaan tersebut dapat melaksanakan dan mengungkapkan tanggungjawab sosial dan lingkungannya dengan baik.

Apabila nilai perusahaan tinggi maka kemakmuran bagi pemegang sahamnya akan meningkat pula, sehingga pemegang saham akan menginvestasikan modalnya pada perusahaan tersebut. Sustainability Reporting menjadi bukti bahwa perusahaan beroperasi sesuai dengan peraturan yang ada dan bertanggungjawab atas kepentingan stakeholder-nya. Sustainability Reporting bermanfaat untuk membangun ketertarikan pemegang saham dengan visi jangka panjang dan mendemostrasikan bagaimana meningkatkan nilai perusahaan terkait dengan isu sosial dan lingkungan. Berdasarkan uraian di atas, maka hipotesis penelitian ini adalah sebagai berikut:

$\mathrm{H}_{1}$ : Sustainability Reporting berpengaruh positif pada nilai perusahaan.

Menurut Teori sinyal, semakin tingginya pertumbuhan yang dialami oleh suatu perusahaan maka akan memancarkan nilai positif kepada investor. Pertumbuhan dari suatu perusahaan dapat dilihat pada pertumbuhan aset yang akan memberikan sinyal bahkan perusahaan mampu mengelola sumber daya untuk menghasilkan keuntungan. Kinerja yang baik akan mengakibatkan naiknya permintaan investor untuk membeli saham perusahaan dan akhirnya meningkatkan nilai perusahaan.

Sustainability Reporting adalah aspek penting yang diterbitkan dan dibuat oleh perusahaan secara sukarela. Laporan tersebut digunakan untuk 
memperoleh kepercayaan dan dukungan dari pihak investor maupun dari masyarakat. Perusahaan tidak hanya bertanggungjawab dalam single bottom line saja, melainkan juga pada triple bottom line.

Apabila profitabilitas semakin tinggi maka perusahaan akan semakin besar dalam pengungkapan informasi ekonomi, sosial, dan lingkungan dalam tanggungjawab sosial. Semakin tinggi profitabilitas sebuah perusahaan dan pengungkapan Sustainability Reporting, maka nilai perusahaan juga akan meningkat. Hal tersebut terjadi karena investor lebih tertarik pada perusahaan yang mengungkapkan Sustainability Reporting dari pada perusahaan yang tidak melaksanakan atau mengungkapkan Sustainability Reporting. Dengan demikian semakin tingginya profitabilitas akan memperkuat pengaruh Sustainability Reporting terhadap nilai perusahaan. Berdasarkan uraian di atas, maka hipotesis penelitian ini adalah sebagai berikut:

$\mathrm{H}_{2}$ : Profitabilitas memperkuat pengaruh Sustainability Reporting pada nilai perusahaan.

Nilai perusahaan merupakan persepsi investor mengenai tingkat keberhasilan perusahaan untuk mensejahterakan pemegang saham. Harmono (2009:233) menyatakan bahwa nilai perusahaan adalah kinerja perusahaan yang dicerminkan oleh harga saham yang dibentuk oleh permintaan dan penawaran pasar modal yang merefleksikan penilaian masyarakat terhadap kinerja perusahaan. Menurut Suka (2016) perusahaan akan mengambil keputusan untuk memaksimalkan nilai perusahaannya. Maksudnya adalah mewujudkan kemakmuran bagi pemegang saham (Brigham \& Gapenski, 1996). Nilai perusahaan akan tinggi apabila semakin tinggi pula harga sahamnya. Menurut Tjahjono (2013), cerminan dari keputusan investasi adalah kemakmuran stakeholders dan perusahaan yang direpresentasikan oleh harga saham yang di pasar modal.

Kemampuan suatu perusahaan untuk menghasilkan laba selama periode tertentu merupakan pengertian dari profitabilitas. Profitabilitas adalah aspek yang penting untuk dijadikan acuan oleh investor atau pemilik perusahaan untuk menilai kinerja manajemen guna untuk mengelola perusahaannya. Selain itu profitabilitas juga merupakan faktor yang membuat manajemen menjadi fleksibel untuk mengungkapkan pertanggungjawaban sosial kepada pemegang saham. MenurutN. Burhan \& Rahmanti (2012) intensitas pengungkapan sosial berpengaruh positif pada profitabilitas perusahaan. Hal tersebut terjadi karena dengan adanya pengungkapan aspek sosial dapat memberikan informasi tanggungjawab sosial kepada klien, karyawan, dan masyarakat.

\section{METODE PENELITIAN}

Penelitian ini dilakukan pada perusahaan-perusahaan yang memenangkan Indonesian Sustainability Reporting Awards (ISRA) pada periode 20152018.Populasi dalam penelitian ini adalah perusahaan pemenang ISRA selama empat periode (2015-2018). Populasi dalam penelitian ini sejumlah 57 perusahaan. Sampel yang digunakan dalam penelitian ini adalah perusahaan pemenang ISRA selama empat periode (2015-2018). Data kuantitatif dalam penelitian ini adalah sustainability reporting, nilai perusahaan yang diambil dari laporan keuangan tahunan (annual report) untuk periode tahun 2015-2018. Data- 
data tersebut diperoleh dari Bursa Efek Indonesia melalui website www.idx.co.id, dan website perusahaan terkait.

\section{HASIL DAN PEMBAHASAN}

Uji statistik deskriptif ditunjukkan pada Tabel 1. menunjukan statistik deskriptif sampel penelitian.

Tabel 1. Hasil Uji Statistik Deskriptif

\begin{tabular}{llllll}
\hline & $\mathrm{N}$ & Minimum & Maximum & Mean & $\begin{array}{l}\text { Std. } \\
\text { Deviation }\end{array}$ \\
\hline Nilai Perusahaan (Y) & 52 & .96 & 1.00 & .9988 & .00540 \\
Sustainability & 52 & .08 & .49 & .2185 & .10178 \\
Reporting (X1) & & & & & \\
Profitabilitas (X2) & 52 & -.06 & .47 & .0644 & .10904 \\
Valid N (listwise) & 52 & & & & \\
\hline
\end{tabular}

Sumber: Data Penelitian, 2019

Nilai rata-rata Nilai Perusahaan dari 52 sampel adalah sebesar 0,9988, nilai tersebut lebih rendah dibandingkan dengan nilai maksimumnya sebesar 1,00 yang terdapat pada PT Bakrie \& Brothers Tbk tahun 2017.Nilai rata-rata Sustainability Reporting dari 52 sampel adalah sebesar 0,2185 dengan standar deviasi sebesar 0,10178. Perusahaan dengan pengungkapan Sustainability Reporting terendah adalah PT Bank Rakyat Indonesia (Persero) Tbk tahun 2017 dengan nilai sebesar 0,08 sedangkan pengungkapan Sustainability Reporting tertinggi adalah PT Vale Indonesia Tbk tahun 2015 dengan nilai sebesar 0,49.Dapat diketahui besarnya profitabilitas periode 2015-2018 berada diantara 0,06 dan 0,47. Nilai rata-rata sebesar 0,0644 dengan standar deviasi sebesar 0,10904. Perusahaan dengan profitabilitas terendah adalah PT Bakrie \& Brothers Tbk tahun 2016 dengan nilai sebesar -0,06 sedangkan profitabilitas tertinggi adalah PT Unilever Indonesia Tbk tahun 2018 dengan nilai sebesar 0,47.

Hasil pengujian normalitas terhadap 52 amatan disajikan dalam Tabel 2.

Tabel 2. Hasil Uji Normalitas

\begin{tabular}{lll}
\hline $\mathrm{N}$ & $\mathrm{Z}$ & Asymp.Sig \\
\hline 52 & 0.120 & 0.059
\end{tabular}

Sumber: Data Penelitian, 2019

Berdasarkan Tabel 2. taraf signifikansi untuk persamaan regresi moderasi adalah sebesar 0,059 dengan taraf signifikansi $>0,05$ menunjukkan bahwa data penelitian ini berdistribusi normal.

Tabel 3. Hasil Uji Heteroskedastisitas

\begin{tabular}{ll}
\hline Variabel & Sig. \\
\hline Zx1 & 0.256 \\
Zx2 & 0.167 \\
Zx1_Zx2 & 0.134 \\
\hline
\end{tabular}

Berdasarkan Tabel 3. maka dapat disimpulkan bahwa data terbebas dari heteroskedastisitas. Hal itu ditunjukkan dengan keseluruhan nilai variabel berada pada tingkat signifikansi $>0,05$.

Tabel 4. Hasil Uji Autokorelasi

\begin{tabular}{ll}
\hline DW (Durbin Watson) & Keterangan \\
\hline 1.752 & $\mathrm{du}<\mathrm{dw}<(4-\mathrm{du})$ \\
\hline Sumber: Data Penelitian, 2019 &
\end{tabular}


Berdasarkan Tabel 4. hasil uji autokorelasi menunjukkan nilai DW sebesar 1,752. Hasil tersebut dibandingkan dengan nilai tabel DW menggunakan nilai signifikansi 5\%, jumlah sampel (n) 52 dan jumlah variabel bebas $3(k=3)$ diperoleh nilai $\mathrm{dL}=1,4339$ dan $\mathrm{dU}=1,6769$. Oleh karena $\mathrm{du}<\mathrm{dw}<4$-du yaitu $1,6769<1,752<2,3231$ maka dalam penelitian ini tidak terjadi gejala autokorelasi. Semua uji asumsi klasik telah memenuhi syarat maka uji nilai selisih mutlak dilanjutkan.

Tabel 5. Hasil Uji Moderated Regression Analysis (MRA)

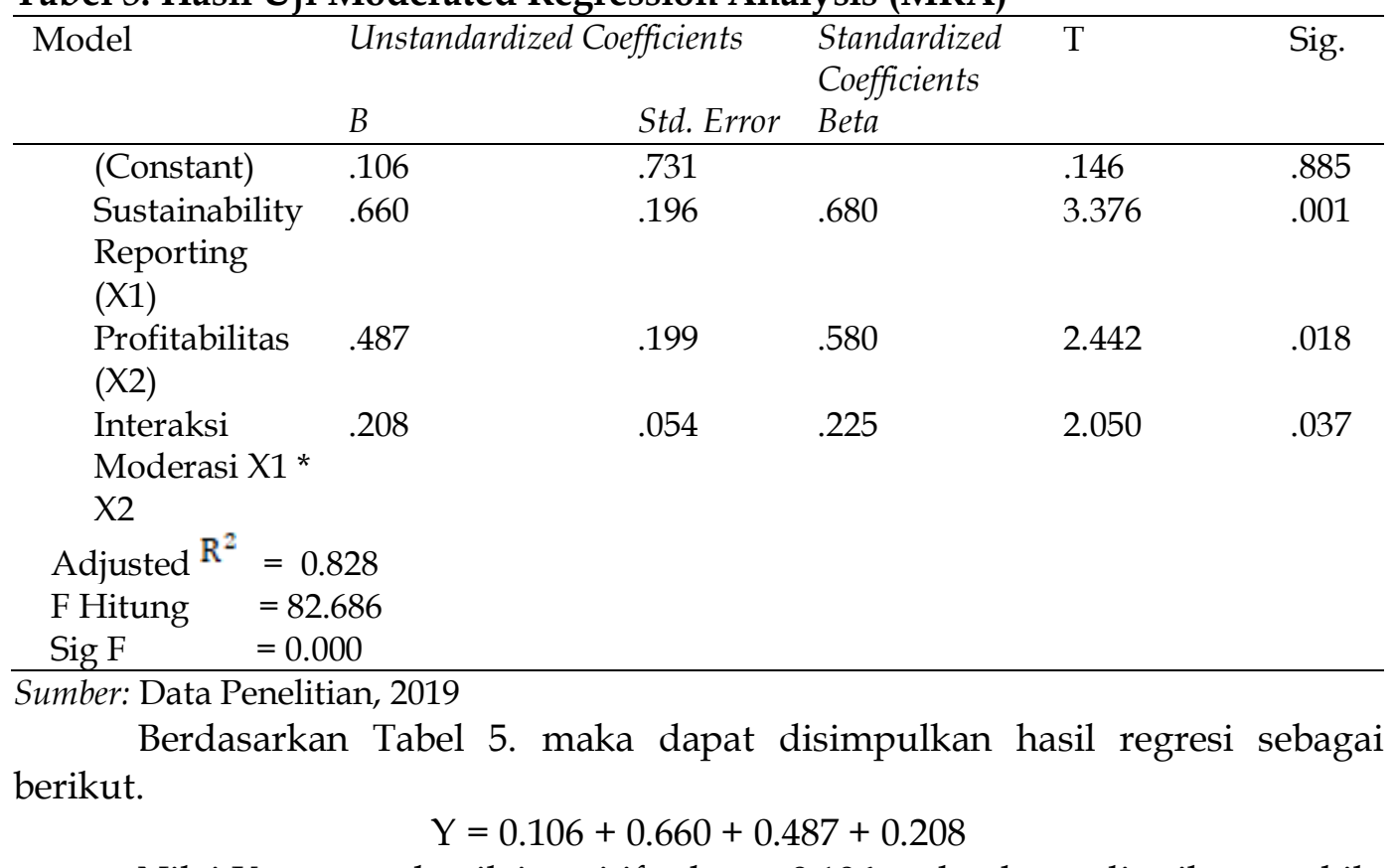

Nilai Konstanta benilai positif sebesar 0.106 maka dapat diartikan apabila tidak terdapat pengaruh dari variable lain atau variable bebas, maka nilai konstan dari variable Nilai Perusahaan (Y) adalah sebesar 0.106.Nilai koefisien Variabel Sustainability Reporting (X1) bernilai positif sebesar 0.660 maka artinya apabila nilai Sustainability Reporting (X1) naik satu satuan maka Nilai Perusahaan (Y) akan naik sebesar 0.660, sehingga dapat disimpulkan bahwa Sustainability Reporting (X1) Berpengaruh Positif terhadap Nilai Perusahaan (Y).Nilai koefisien Variabel Profitabilitas (X2) bernilai positif sebesar 0.487 maka artinya apabila nilai Profitabilitas (X2) naik satu satuan maka Nilai Perusahaan (Y) akan naik sebesar 0.487, sehingga dapat disimpulkan bahwa Profitabilitas (X2) Berpengaruh Positif terhadap Nilai Perusahaan (Y).

Nilai koefisien Variabel Interaksi Moderasi X1 * X2 bernilai positif sebesar 0.208 maka artinya apabila nilai Interaksi Moderasi X1 * $\mathrm{X} 2$ naik satu satuan maka Nilai Perusahaan (Y) akan naik sebesar 0.037, sehingga dapat disimpulkan bahwa Interaksi Moderasi X1 * X2 (X3) Memberi pengaruh Positif Sustainability Reporting (X1) terhadap Nilai Perusahaan $(\mathrm{Y})$.

Uji kelayakan model (Uji F) digunakan untuk mengetahui apakah model regresi Moderated Regression Analysis (MRA) dalam penelitian ini layak digunakan atau tidak. Pada Tabel 5 nilai $F$ hitung sebesar 82,686 dengan signifikansi sebesar 0,000. Nilai ini lebih kecil dari 0,05. Jadi dapat disimpulkan bahwa model Moderated Regression Analysis (MRA) layak digunakan. 
Hasil pengujian hipotesis menunjukkan bahwa Sustainability Reporting memiliki nilai sebesar 3,376 dengan tingkat signifikansi sebesar 0,001 nilai ini lebih kecil dari 0,05. Sehingga dapat disimpulkan bahwa terdapat pengaruh signifikan secara parsial antara Sustainability Reporting terhadap Nilai Perusahaan. Hasil pengujian hipotesis menunjukkan bahwa Interaksi Moderasi memiliki nilai sebesar 2,050 dengan nilai signifikansi sebesar 0,037 nilai ini lebih kecil dari 0,05 sehingga dapat disimpulkan bahwa Variabel Profitabilitas (X2) dapat memoderasi pengaruh Variabel Sustainability Reporting (X1) Terhadap Nilai Perusahaan (Y).

Sustainability Reporting (SR) merupakan suatu laporan yang diterbitkan oleh suatu perusahaan untuk mengungkapkan kinerja perusahaannya baik aspek ekonomi, sosial, dan lingkungan serta untuk menjadi perusahaan yang akuntabel bagi stakeholder. Dengan adanya Sustainability Reporting (SR) maka perusahaan akan dapat meningkatkan citra perusahaan dimata stakeholder, dengan citra yang baik perusahaan dapat meningkatkan loyalitas konsumen terhadap perusahaan, sehingga secara tidak langsung dapat meningkatkan nilai perusahaan yang tercermin dari harga sahamnya.

Sesuai dengan penelitian yang dilakukan oleh Hafni (2018) dan Habibi (2017) menunjukkan bahwa Sustainability Reporting berpengaruh positif terhadap nilai perusahaan. Teori sinyal dapat memprediksi hubungan positif antara Sustainability Reporting dan nilai perusahaan. Perusahaan akan memberikan informasi pada investor dalam pengambilan keputusan investasinya, apabila pengumuman tersebut bernilai positif maka pasar akan bereaksi pada waktu pengumuman tersebut diterima. Kualitas Sustainability Reporting memiliki pengaruh yang positif pada kinerja pasar perusahaan, apabila investor melihat bahwa dengan diterbitkannya Sustainability Reporting meni ngkatkan modal perusahaan, hal tersebut akan meningkatkan nilai perusahaan.

Berdasarkan teori sinyal perusahaan yang mengalami peningkatan laba mencerminkan bahwa perusahaan mempunyai kinerja yang baik, sehingga mendapat respon positif dari investor dan dapat membuat harga saham perusahaan mengalami peningkatan, meningkatnya harga saham dipasar berarti meningkat pula nilai perusahaan dimata investor. Semakin tinggi tingkat profitabilitas perusahaan maka akan memperkuat pengaruh positif pengungkapan sosial dengan nilai perusahaan.

Temuan penelitian ini memberikan bukti empris dan konsisten dengan teori sinyal. Dengan perusahaan yang mencapai profitabilitas yang tinggi maka dapat dipandang sebagai good news. Oleh karena itu, perusahaan cenderung untuk sesegera mungkin menyampaikan informasi tersebut kepada pasar. Informasi mengenai profitabilitas tersebut merupakan sinyal yang kemudian disampaikan, dan Sustainability Reporting akan merespon sinyal positif yang diberikan sehingga akan meningkatkan nilai perusahaan.

Hasil penelitian ini tidak sesuai dengan hasil penelitian Kusuma (2018). Hasil penelitian tersebut menyimpulkan bahwa profitabilitas tidak memoderasi hubungan antara Sustainability Reporting pada nilai perusahaan. Hal tersebut berarti perusahaan yang memiliki profitabilitas tinggi tidak mampu meningkatkan pengungkapan Sustainability Reporting, sehingga nilai perusahaan juga tidak meningkat. Hasil tersebut memperlihatkan bahwa profitabilitas 
sebagai pemoderasi memperlemah pengaruh Sustainability Reporting pada nilai perusahaan

Berdasarkan penelitian yang telah dilakukan dapat diketahui bahwa secara teoritis, penelitian ini mendukung teori sinyal dan teori stakeholder. Penelitian ini dapat menjadi suatu hal baru untuk penelitian yang berhubungan dengan variabel Sustainability Reporting, profitabilitas, dan nilai perusahaan. Pengolahan data dilakukan dengan menggunakan Moderated Regression Analysis (MRA) untuk memperkirakan hubungan antara variabel - variabel yang telah ditetapkan sebelumnya berdasarkan teori. Hasil penelitian ini dapat digunakan untuk memperkaya referensi yang berkaitan dengan Sustainability Reporting, profitabilitas, dan nilai perusahaan.

Hasil penelitian ini dapat menjadi bahan pertimbangan bagi investor maupun calon investor dalam mengambil keputusan untuk berinvestasi dengan melihat Sustainability Reporting, profitabilitas dan nilai perusahaan sehingga tidak hanya terpaku pada ukuran-ukuran moneter. Maka dari itu, investor harus membeli saham pada perusahaan yang telah menerbitkan Sustainability Reporting. Karena perusahaan yang telah mampu bertanggung jawab atas Sustainability Reporting, maka perusahaan dinilai telah memiliki etika bisnis yang baik.

\section{SIMPULAN}

Pengungkapan Sustainability Reporting berpengaruh positif pada nilai perusahaan pemenang Indonesian Sustainability Reporting Awards (ISRA) tahun 2015-2018. Hal ini memiliki makna bahwa semakin banyak pengungkapan Sustainability Reporting yang dilakukan perusahaan pemenang Indonesian Sustainability Reporting Awards (ISRA), maka semakin tinggi nilai perusahaan tersebut. Profitabilitas memperkuat pengaruh Sustainability Reporting pada nilai perusahaan pemenang Indonesian Sustainability Reporting Awards (ISRA) 20152018. Artinya semakin tinggi profitabilitas perusahaan pemenang Indonesia Sustainability Reporting Awards (ISRA), maka akan meningkatkan pengaruh positif pengungkapan Sustainabily Reporting pada nilai perusahaan.

Bagi pihak perusahaan, diharapkan berkomitmen untuk mengungkapkan Sustainability Reporting secara lebih konsisten. Selain itu, perusahaan juga diharapkan mengungkapkan kegiatan tersebut secara sukarela dalam Sustainability Report sesuai dengan standar yang telah ditetapkan Global Reporting Index (GRI). Hal tersebut dilakukan demi kelangsungan usaha dalam jangka panjang dan eksistensi serta memberikan manfaat lebih luas untuk seluruh stakeholder. Dengan demikian, diharapkan dapat meningkatkan nilai Perusahaan. Bagi pihak stakeholder terutama pihak investor yang berhubungan langsung dengan perusahaan agar memperhatikan pengungkapan Sustainability Reporting yang dilakukan oleh manajemen perusahaan. Hal ini disebabkan karena dengan perusahaan melakukan pengungkapan Sustainability Reporting, maka perusahaan telah memiliki tanggung jawab dan etika bisnis yang baik, sehingga layak dijadikan target investasi.Bagi peneliti selanjutnya, diharapkan menggunakan proksi lain, seperti Price to Earning Ratio (PER). Penggunaan proksi lain diharapkan mampu menggambarkan variabel Nilai Perusahaan. Selain itu, penelitian ini menggunakan Return on Total Aset (ROA) untuk 
memproksikan Profitabilitas. Peneliti selanjutnya dapat menggunakan proksi lain, seperti Margin Laba atas Penjualan, ROE, dan BEP. Penggunaan proksi lain diharapkan mampu menggambarkan variabel Profitabilitas.

\section{REFERENSI}

Aktas, R., Kayalidere, K., \& Kargin, M. 2013. Corporate Sustainability Reporting and Analysis of Sustainability Reports in Turkey. International Journal of Economics and Finance, 5(3), 113-125.

Astuti, A.D \& Juwenah. 2017. Pengaruh Pengungkapan Sustainability Report terhadap Nilai Perusahaan yang tergabung dalam LQ 45 Tahun 20122013. Journal of Accounting and Finance, Vol. 2 No. 01, 301-313.

Brigham, E., F., dan Gapenski, L. C. 1996. Intermadiate finance management, 5th ed. Harbor Drive: The Dryden Press.

Bukhori, Mochamad Rizki Triansyah \& Dani Sopian. 2017. Pengaruh Pengungkapan Sustainability Report Terhadap Kinerja Keuangan, Jurnal SIKAP. Vol 2

Chairina and Enny Hardi. 2019. The Effect of Sustainability Reporting Disclosure and Its Impact on Companies' Finance Performance, Directorate General of Higher Education Indonesia.Vol 7

Chariri, A., dan Ghozali, I. 2007. Teori Akuntansi. Semarang: Badan Penerbit UNDIP.

Diantimala, Y. 2018. The Mediating Effect of Sustainability Disclosure on the Relationship between Financial Performance and Firm Value. Journal of Accounting, Finance and Auditing Studies, 4(2), 32-49.

Effendi, Muhammad Arief. 2009. The Power Of Good Corporate Governance: Teori dan Implementasi. Jakarta: Salemba Empat.

Elkington, J. 1998. Partnerships from cannibals with forks: The triple bottom line of 21st-century business. Environmental Quality Management.

Eva, K., \& Dewi, C. 2015. Sustainability Reporting Dan Profitabilitas (Studi Pada Pemenang Indonesian Sustainability Reporting Awards). Jurnal Ilmiah Akuntansi dan Bisnis, 1-7.

Frucot, V., dan Shearon, W., T. 1991. Budgetary Participation, Locus of Control, and Mexican Managerial Performance and Job Satisfaction, The Accounting Review. 66 (1). Hal.80-99.

Habibi, M. 2017. Pengaruh Profitabilitas Dan Sustainability Reporting Terhadap Nilai Perusahaan. Ekonomi dan Bisnis Islam.

Hafni, Afnia Fauzia. 2018. Pengaruh Pengungkapan Sustainability Reporting dan Intellectual Capital Terhadap Nilai Perusahaan (Studi Empiris Perusahaan Sektor Pertambangan yang Terdaftar di BEI Tahun 20112015). Skripsi. Fakultas Ekonomi dan Bisnis Universitas Negeri Yogyakarta.

Hardi, E. 2018. The Effect of Sustainability Reporting Disclosure and Its Impact on Companies ' Financial Performance, 5844(21), 67-75.

Harmono. 2009. Manajemen Keuangan Berbasis Balanced Scorecard (Pendekatan Teori, Kasus, dan Riset Bisnis). Jakarta: Bumi Aksara

Handoko, H. 2010. Manajemen Personalia Sumber Daya Manusia, Edisi Kedua. BPFE UGM Persada. 
Hermuningsih, S \& Wardani, D. K. 2009. Faktor-Faktor yang Memengaruhi Nilai Perusahaan pad a Perusahaan yang Terdaftar di Bursa Efek Malaysia dan

Bursa Efek Indonesia. Jurnal Siasat Bisnis, Volume 13, Nomor 2, 173-183.

Jogiyanto, Hartono. 2007. Teori Portofolio dan Analisis Investasi. Yogyakarta: BPFE.

Kurniawan, T., Sofyani, H., \& Rahmawati, E. 2018. Pengungkapan Sustainability Report dan Nilai Perusahan: Studi Empiris di Indonesia dan Singapura. Kompartemen: Jurnal Ilmiah Akuntansi, 16(1), 1-20.

Kusuma, Rr Aurin Wahyu. 2018. Pengaruh Pengungkapan Sustainability Report Dan Ukuran Perusahaan Terhadap Nilai Perusahaan Dengan ProfitabilitasSebagai Variabel Pemoderasi Pada Perusahaan Yang Bergabung Di ISSI Dan Konvensional Periode 2014-2016. Skripsi. Sarjana Jurusan Akuntansi pada Fakultas Ekonomi dan Bisnis Universitas Negeri Yogyakarta, Yogyakarta.

Lesmana, Y., \& Tarigan, J. 2014. Pengaruh sustainability Reporting terhadap Kinerja Keuangan Perusahaan Publik dari sisi Aset Management Ratios. Business Accounting Review, 2(1), 101-110.

Loh, L., Thomas, T., \& Wang, Y. 2017. Sustainability reporting and firm value: Evidence from Singapore-listed companies. Sustainability (Switzerland), 9(11), 1-12.

Lu, J. 2010. The Relations Among Environmental Disclosure, Environmental Performance and Financial Performance: An Empirical Study in China.

Luke, O. O., \& Adaramola, A. O. 2013. Triple Bottom Line Reporting: An Assessment of Sustainability in Banking Industry in Nigeria. Asian Journal of Finance \& Accounting.

Matten, D., Crane, A. and Chapple, W. 2003. "Behind the Mask: Revealing the True Face of Corporate Citizenship", Journal of Business Ethics, 45(1/2), h: 109-120.

Maulida, K. A. dan Adam, H. 2012. Faktor- Faktor Yang Mempengaruhi Pengungkapan Sustainability Performance. Jurnal Ilmiah Mahasiswa FEB. Murnita, Putu Elia Meilinda. 2018. Pengaruh Corporate Social Responsibility Terhadap Nilai Perusahaan Dengan Profitabilitas dan Leverage Sebagai Variabel Pemoderasi. Skripsi. Fakultas Ekonomi dan Bisnis Universitas Udayana

N. Burhan, A. H., \& Rahmanti, W. 2012. the Impact of Sustainability Reporting on Company Performance. Journal of Economics, Business, and Accountancy | Ventura, 15(2), 257.

Ningrum, A. I., Akuntansi, P. S., Ekonomi, F., Bisnis, D. A. N., \& Surakarta, U. M. (2018). Pengaruh Profitabilitas Terhadap Nilai Perusahaan Dengan Corporate Social Responsibility Sebagai Variabel Moderating ( Studi Empiris Pada Perusahaan Property dan Real Estate yang Terdaftar di Bursa Efek Indonesia Periode 2013-2015 ).

Octavia, I. (2012). Pengaruh Pengungkapan Lingkungan Terhadap Nilai Perusahaan Dengan Profitabilitas Sebagai Variabel Moderasi.

Okoye, P. V. C., Egbunike, F. C., \& Meduoye, O. M. (2013). Sustainability Reporting: A Paradigm for Stakeholder Conflict Management. International Business Research.

Priyadi. 2017. Pengaruh Publikasi Sustainability Report Terhadap Kinerja Keuangan, Nilai Perusahaan Dan Struktur Modal, 1-10. 
Putra, Tebuana Agung dan Ketut Muliartha RM 2019. Pengaruh Pertumbuhan Perusahaan Pada Nilai Perusahaan Dengan Pengungkapan CSR Sebagai Variabel Pemoderasi.E-Jurnal Akuntansi Universitas Udayana.Vol 26

Putri, K.M.D. 2017. “Pengaruh Sustainability Reporting Disclosure Berdasarkan Global Reporting Initiative (GRI) G4 terhadap Kinerja Perusahaan (Studi pada Perusahaan yang terdaftar di Bursa Efek Indonesia Tahun 20142015)". Skripsi. Fakultas Ekonomi Bisnis, Universitas Lampung.

Reddy, K., \& Gordon, L. W. 2010. The effect of sustainability reporting on financial performance: An empirical study using listed companies. Journal of Asia Entrepreneurship and Sustainability.

ROBINS, F. (2006). The Challenge of TBL: A Responsibility to Whom? Business and Society Review.

Sejati, B. P., \& Prastiwi, A. 2015. Pengaruh Pengungkapan Sustainability Report Terhadap Kinerja dan Nilai Perusahaan. Dipenegoro Journal Of Accounting, 4, 1-12.

Setyastrini, Ni Luh Putri \& I Gde Ary Wirajaya. 2017. Intensitas Pengungkapan Corporate Sosial Responsibility: Pengujian Dengan Manajemen Laba Akrual dan Riil, Jurnal Akuntansi Universitas Udayana. Vol 19

Sugiyono. 2017. Metode Penelitian Kuantitatif, Kualitatif, dan RED, Bandung: Alfabeta

Suka, E. A. 2016. Efektivitas Akuntansi Lingkungan dalam Meningkatkan Nilai Perusahaan. Universitas Muhammadiyah Yogyakarta.

Tjahjono, M. E. S. 2013. Pengaruh Kinerja Lingkungan terhadap Nilai Perusahaan dan Kinerja Keuangan. E-Jurnal Ekonomi, 4(1), hal.38-46.

Verrecchia, R. E. 1983. Discretionary disclosure. Journal of Accounting and Economics, 5(1), hal.179-194.

Zenovia, Grigore Maria dan Anca Bratu. 2009. Theoretical Aspects Of Firms' Financing Decisions. The International Conference on Economics and Administration, Faculty of Administration and Business, 12(2): h: 122-129 